\title{
KEBIJAKAN UPAH MINIMUM KABUPATEN/KOTA : STUDI IMPLEMENTASI PADA PERUSAHAAN DI KABUPATEN KARAWANG
}

\author{
Siska Widianti Motip ${ }^{1,}$ Hanny Purnamasari ${ }^{2}$, Ani Nurdiani Azijah ${ }^{3}$ \\ Universitas Singaperbangsa Karawang \\ 1610631180188@student.unsika.ac.id
}

\begin{abstract}
Abstrak
Penelitian ini dilatar belakangi karena adanya fenomena di masyarakat bahwa kenaikan jumlah upah minimum khususnya di Kabupaten Karawang setiap tahunnya menimbulkan permasalahan diantaranya pengurangan pekerja/buruh dan perusahaan yang tutup atau pindah keluar daerah karena tidak sanggup membayar besaran upah minimum di Kabupaten Karawang. Dari uraian latar belakang tersebut, tujuan dalam penelitian ini adalah untuk mengetahui sejauh mana keberhasilan implementasi kebijakan tentang upah minimum Kabupaten/Kota pada perusahaan di Kabupaten Karawang menurut teori implementasi Van Meter dan Van Horn (dalam Winarno, 2013 : 158). Metode penelitian menggunakan metode deskritif dengan pendekatan kualitatif. Data diperoleh melalui studi pustaka dan wawancara mendalam dengan informan yang berkaitan dengan fokus penelitian ini. Teknik pengolahan dan analisis data dilakukan melalui tiga kegiatan yang terjadi secara bersamaan yaitu reduksi data, penyajian data, dan penarikan kesimpulan atau verifikasi. Berdasarkan hasil penelitian bahwa pelaksanaan implementasi kebijakan upah minimum pada perusahaan di Kabupaten Karawang berjalan dengan baik dan lancar, namun terdapat beberapa kekurangan yang perlu diperhatikan. Seperti ketidaksempurnaan hukum atau cacat hukum yang terjadi pada saat musyawarah penetapan UMK Karawang 2020 karena tidak ada kesepakatan antara pengusaha dan pekerja/buruh.
\end{abstract}

Kata Kunci: Implementasi Kebijakan, Upah Minimum Kabupaten/Kota, Kabupaten Karawang.

\begin{abstract}
This research is motivated by a phenomenon in society that increases the amount of minimum wages especially in Karawang Regency, every year it creates problems including reduction workers/laborers and companies that have closed or moved out of the region because they are unable to pay the amount of wages minimum in Karawang Regency. From the background descrition, the purpose of this study is to know The success of implementing policies on district / city minimum wages in companies in Karawang Regency according to the theory of implementation of Van Meter and Van Horn (in Winarno, 2013: 158). Method this research uses descriptive method with a qualitative approach. Data obtained through literature and in-depth interviews with informants related to the focus of this research. Processing and analysis techniques the data is carried out through three activities that occur simultaneously, namely data reduction, data presentation and conclusion or verification. Based on the research results that the implementation of the minimum wage policy the companies in Karawang Regency are running well and smoothly, but there are several shortcomings that needs attention. Such as legal imperfections or legal defects that occur during deliberation determination of the 2020 UMK Karawang because there is no agreement between the entrepreneur and the worker/laborer.
\end{abstract}

Keywords: Policy Implementation, Regency/City Minimum Wage, Karawang Regency. 


\section{A. PENDAHULUAN}

Tingkat kesejahteraan buruh di Indonesia masih dikatakan belum memadai misalnya dalam hal pengupahan. Besaran upah yang diterima pekerja atau buruh setiap bulannya masih relatif murah. Menurut data Badan Pusat Statistik yang dikutip oleh website kumparan.com (20/5/2019), rata-rata gaji pekerja atau buruh di Indonesia hanya sebesar Rp 2,79 juta per bulan. Besaran upah yang masih rendah tersebut, memerlukan perlindungan terhadap tenaga kerja untuk menjamin hakhak dasar pekerja/buruh untuk mewujudkan kesejahteraan pekerja/buruh dan keluarganya dengan tetap memperhatikan perkembangan kemajuan dunia usaha.

Pemerintah menetapkan kebijakan besaran upah minimum dimana pengusaha tidak boleh membayarkan upah kepada pekerja/buruh dibawah upah minimum yang telah ditetapkan. Upah minimum yang berlaku di Kabupaten Karawang yaitu sebesar Rp. 4.594.324,54 yang tercantum dalam Keputusan Gubernur Jawa Barat Nomor 561/Kep.983-Yanbangsos/2019 Tentang Upah Minimum Kabupaten/Kota di Daerah Provinsi Jawa Barat Tahun 2020. Kebijakan Upah Minimum Kabupaten/Kota (UMK) ini sangat mempengaruhi kesanggupan perusahaan untuk membayarkan upah kepada para pekerja/buruhnya sesuai dengan jumlah UMK yang telah ditetapkan. Pada tahun 2019, sebanyak 5 (lima) perusahaan tidak mampu menerapkan kebijakan UMK sehingga perusahaannya tutup dan 1 (satu) perusahaan terpaksa mengurangi jumlah pekerja/buruh agar perusahaannya tetap berproduksi.

Kenaikan UMK tahun 2020 merupakan suatu tantangan baik untuk Pemerintah, pengusaha maupun pekerja/buruh itu sendiri. Kebijakan dengan menaikan jumlah UMK pada tahun 2020 telah menimbulkan dampak yang tidak menguntungkan baik bagi pengusaha maupun pekerja/buruh pabrik di Kabupaten Karawang. Dari uraian yang telah dikemukakan pada latar belakang tersebut, peneliti tertarik untuk meneliti lebih lanjut mengenai implementasi kebijakan Upah Minimum Kabupaten/Kota (UMK) pada perusahaan di Kabupaten Karawang.
Telah dilakukan berbagai penelitian tentang kebijakan upah minimum (Herlina, 2018), (Kistanto, 2013), (Azim, 2018) dengan hasil yang bervariasi misalnya terdapat perusahaan yang masih membayarkan upah kepada pekerja/buruh masih dibawah upah minimum yang ditetapkan pemerintah. Adapun beberapa perbedaan antara penelitian ini dengan penelitian-peneritian sebelumnya yaitu:

1. Teori yang digunakan dalam penelitian ini berbeda dengan teori dalam penelitian-penelitian sebelumnya. Teori dalam penelitian ini adalah teori model implementasi menurut Van Meter dan Van Horn, dimana keberhasilan suatu impelemtasi kebijakan dipengaruhi enam faktor: Ukuran-ukuran dasar dan tujuan-tujuan kebijakan, Sumbersumber kebijakan, Komunikasi antar organisasi dan kegiatan-kegiatan pelaksanaan, Karakteristik badanbadan pelaksana, Kondisi-kondisi ekonomi, sosial, dan politik, dan Kecenderungan pelaksana (implementors).

2. Lokasi penelitian ini berbeda dengan lokasi dalam penelitian-penelitian sebelumnya. Lokasi dalam penelitian ini adalah di kantor Dinas Tenaga Kerja dan Transmigrasi Kabupaten Karawang serta kantor Asosiasi Pengusaha Indonesia (APINDO) Kabupaten Karawang.

Berdasarkan uraian latar belakang di atas, tujuan penelitian ini untuk mengetahui sejauh mana keberhasilan implementasi kebijakan upah minimum pada perusahaan di Kabupaten Karawang dengan berfokus pada 6 (enam) dimensi dari teori implementasi menurut Van Meter dan Van Horn (Dalam Winarno, 2013: 158) yaitu: Ukuran-ukuran dasar dan tujuan-tujuan kebijakan, Sumber-sumber kebijakan, Komunikasi antar organisasi dan kegiatankegiatan pelaksanaan, Karakteristik badanbadan pelaksana, Kondisi-kondisi ekonomi, sosial, dan politik, Kecenderungan pelaksana (implementors).

\section{B. METODE PENELITIAN}

Metode penelitian yang digunakan adalah metode deskritif dengan pendekatan kualitatif. Data diperoleh melalui studi pustaka dan wawancara mendalam dengan 
informan sebagai berikut, Kasi Bidang Persyaratan Kerja, Pengupahan, dan Norma Ketenagakerjaan Dinas Tenaga Kerja dan Transmigrasi Kabupaten Karawang, Kepala Bidang Pengupahan DPK Apindo Karawang, Federasi Serikat Pekerja Metal Indonesia (FSPMI) Pimpinan Unit Kerja PT. NT Piston Ring Indonesia dan pekerja/buruh yang bekerja di bidang industri. Teknik pengolahan dan analisis data dilakukan melalui tiga kegiatan yang terjadi secara bersamaan yaitu reduksi data, penyajian data, dan penarikan kesimpulan atau verifikasi.

\section{HASIL DAN PEMBAHASAN}

Pembahasan hasil penelitian tentang implementasi kebijakan upah minimum kabupaten/kota pada perusahaan di Kabupaten Karawang dapat dipaparkan sebagai berikut:

1. Ukuran-Ukuran Dasar dan TujuanTujuan Kebijakan.

Dimensi ukuran-ukuran dasar dan tujuan-tujuan kebijakan diketahui bahwa ukuran dan tujuan dalam kebijakan upah minimum pada perusahaan di Kabupaten Karawang sudah cukup jelas dan mudah dipahami oleh pengusaha/perusahaan sebagai pelaksana utama dari kebijakan tersebut. Kebijakan upah minimum pertama kali muncul tahun 1969 setelah dibentuknya Dewan Penelitian Pengupahan Nasional berdasarkan Keputusan Presiden Nomor 85 Tahun 1969 Tentang Mencabut Keputusan Presidium Kabinet Nomor 43/U/Kep/9/1966. Namun istilah Upah Minimum Kabupaten/Kota muncul ketika diterbitkannya Keputusan Menteri Tenaga Kerja dan Transmigrasi Republik Indonesia Nomor Kep-226/Men/2000 Tentang Perubahan Pasal 1, Pasal 3, Pasal 4, Pasal 8, Pasal 11, Pasal 20, dan Pasal 21 Peraturan Menteri Tenaga Kerja Nomor Per-01/Men/1999 Tentang Upah Minimum.

Kebijakan upah minimum yang ditentukan oleh pemerintah digunakan untuk melindungi hak-hak buruh dari upah yang murah. Upah minimum Kabupaten Karawang tahun 2020 mencapai angka Rp 4.594.324,54 dikarenakan mengalami kenaikan sebesar 8,51 persen yang mengacu pada inflasi dan pertumbuhan ekonomi nasional dan merupakan UMK tertinggi di Indonesia.
Adapun ukuran-ukuran dasar ataupun kriteria sasaran dari implementasi kebijakan upah minimum pada perusahaan di Kabupaten Karawang yaitu, pekerja/buruh yang masa kerjanya kurang dari 1 (satu) tahun dan terikat perjanjian kerja dengan perusahaan terkait. Sedangkan untuk pekerja yang masa kerjanya lebih dari 1 (satu) tahun, pengusaha/perusahaan merumuskan kembali skala upah dengan ketentuan tidak boleh lebih kecil dari upah minimum yang telah ditentukan. Sedangkan yang menjadi ukuran kebijakan ini berhasil adalah tercapainya tujuan dari implementasi kebijakan ini, yaitu pekerja/buruh terlindungi dari pembayaran upah murah dan tidak sesuai dengan KHL (Kebutuhan Hidup Layak), kesejahteraan hidup pekerja/buruh meningkat khususnya kesejahteraan secara finansial sehingga dapat memenuhi kebutuhan hidup pekerja/buruh dan keluarganya minimal kebutuhan sandang, pangan, dan keperluan rumah tangga lainnya. Hal tersebut ditandai dengan penurunan jumlah presentase penduduk miskin di Kabupaten Karawang dalam kurun waktu 3 (tiga) tahun terakhir yang disajikan dalam tabel 1.1 berikut:

Tabel 1.1

Presentase Penduduk Miskin di Kabupaten Karawang

Tahun 2017-2019

No. Tahun Presentase Penduduk Miskin

\begin{tabular}{ccc} 
& & (Persen) \\
\hline 1. & 2017 & 10,25 \\
2. & 2018 & 8,06 \\
3. & 2019 & 7,39 \\
\hline
\end{tabular}

Sumber: https://karawangkab.bps.go.id

Berdasarkan data diatas, kebijakan upah minimum Kabupaten/Kota yang diimplementasikan oleh perusahaan berhasil membawa dampak baik kepada masyarakat salah satunya dapat membantu mengurangi angka kemiskinan khususnya di Kabupaten Karawang sejak tahun 2017.

2. Sumber-Sumber Kebijakan.

Keberhasilan proses implementasi kebijakan sangat tergantung dari kemampuan untuk memanfaatkan sumbersumber daya yang tersedia. Dalam proses implementasi kebijakan UMK di Kabupaten Karawang, sumber daya manusia yang terlibat adalah pengusaha atau investor 
yang mendirikan perusahaan sebagai leading sector pelaksana kebijakan tersebut. Terdapat 5 (lima) negara besar yang mendominasi investasi asing di Kabupaten Karawang yaitu China, Jepang, Korea Selatan, Belanda, dan Singapura dengan total realisasi investasi sebesar Rp. 24,2 Triliun pada tahun 2019 (dalam website regional.kompas.com, 11 Februari 2020). Dari besaran nilai investasi tersebut, berdasarkan data yang dikutip oleh radarsukabumi.com (18/06/2020) terdapat 950 (sembilan ratus lima puluh) perusahaan yang beroperasi di Kabupaten Karawang.

Berdasarkan Undang-Undang

Republik Indonesia Nomor 13 Tahun 2003 Tentang Ketenagakerjaan, karakteristik perusahaan yang wajib menerapkan upah minimum yang ditetapkan oleh pemerintah yaitu setiap bentuk usaha yang berbadan hukum atau tidak, milik orang perseorangan, milik persekutuan, atau milik badan hukum, baik itu swasta maupun milik negara yang mempunyai pengurus dan mempekerjakan pekerja/buruh. Selain pengusaha atau investor yang mendirikan perusahaan, sumber daya yang terlibat dalam implementasi kebijakan upah minimum di Kabupaten Karawang yaitu Pemerintah, yang melakukan kegiatan pengawasan dalam proses penerapan kebijakan tersebut. Pemerintah juga menjadi fasilitator atau penengah antara pekerja/buruh dengan pihak pengusaha/perusahaan jika terjadi permasalahan terkait hal-hal yang bersifat industrial dan melanggar peraturan perundang-undangan.

Sumber daya finansial dalam implementasi kebijakan upah minimum di Kabupaten Karawang bersumber dari keuntungan penjualan hasil produksi dari masing-masing perusahaan. Berdasarkan temuan peneliti terdapat hambatan dalam pengadaan anggaran untuk menerapkan kebijakan upah minimum di Kabupaten Karawang. Di tengah pandemi Covid-19 ini kegiatan produksi di perusahaanperusahaan mengalami penurunan drastis karena tidak ada permintaan barang dari konsumen. Hal tersebut menyebabkan perusahaan tidak mampu membayar upah semua pekerja/buruh, sehingga perusahaan memutuskan untuk mengurangi pekerja/buruhnya atau bahkan tutup (bankrut).

3. Komunikasi Antar Organisasi dan Kegiatan-Kegiatan Pelaksanaan.

Koordinasi merupakan salah satu bentuk atau cara komunikasi dengan para pelaksana dalam proses penerapan sebuah kebijakan. Koordinasi yang terjadi antara pengusaha atau perusahaan dengan pemerintah pada implementasi kebijakan upah minimum di Kabupaten Karawang hanya dilakukan 1 (satu) kali dimana saat pengusaha atau perusahaan melaksanakan wajib lapor kepada Dinas Tenaga Kerja dan Transmigrasi Kabupaten Karawang, Selain itu, koordinasi yang terjadi antara Pemerintah Kabupaten Karawang dengan pengusaha atau perusahaan dilakukan melalui sosialisasi kebijakan upah minimum dengan mengirimkan surat-surat pemberitahuan kepada perusahaanperusahaan di Kabupaten Karawang. Pemerintah juga memanfaatkan teknologi telekomunikasi melalui media sosial seperti Whatsapp untuk menyampaikan informasi dan menjalin komunikasi yang baik dengan pihak pengusaha atau perusahaan.

Peran Pemerintah Kabupaten Karawang dalam menjalin koordinasi dengan pengusaha atau perusahaan dan serikat pekerja/buruh yaitu sebagai wadah yang memfasilitasi penyampaian aspirasi dari pekerja/buruh untuk disampaikan kepada pihak pengusaha atau perusahaan mengenai hal-hal yang bersifat industrial termasuk dalam hal pengupahan. Dengan demikian, pemerintah memberi ruang kepada pengusaha atau perusahaan dan pihak pekerja/buruh untuk bermusyawarah dan menjalin koordinasi yang harmonis melalui Dewan Pengupahan Kabupaten Karawang.

Komunikasi dan koordinasi yang lebih dominan dilakukan oleh pengusaha atau perusahaan dengan serikat pekerja/buruh melalui musyawarah bipartit di internal perusahaan atau dengan atasan masingmasing pekerja/buruh. Koordinasi yang dilakukan pun hanya berkaitan dengan halhal industrial atau penyelesaian masalah ketenagakerjaan.

4. Karakteristik Badan-Badan Pelaksana.

Karakterikstik badan pelaksana dalam penerapan kebijakan upah minimum di Kabupaten Karawang dapat dilihat dari 
struktur birokrasi dan kompetensi yang dimiliki oleh pelaksana kebijakan. Kebijakan upah minimum yang diterapkan di Kabupaten Karawang adalah kebijakan Upah Minimum Kabupaten/Kota (UMK) Karawang yang dikeluarkan dan disahkan oleh Pemerintah Provinsi Jawa Barat. Pengusaha/perusahaan merupakan agen utama pelaksana dari kebijakan ini, yaitu untuk membayarkan upah tidak boleh rendah dari UMK yang berlaku.

\section{Asosiasi Pengusaha Indonesia}

(APINDO) Kabupaten Karawang merupakan salah satu agen pelaksana kebijakan upah minimum. APINDO Kabupaten Karawang memiliki kompetensi yang cukup memadai terutama dalam hal ketenagakerjaan, seperti pelatihan mengenai kenyamanan berbisnis bersama Tim Ekonom Universitas Padjajaran dan studi banding dengan Kementrian Kesehatan, Tenaga Kerja, dan Sosial (Kosei rodo sho) Jepang. APINDO Kabupaten Karawang diharuskan menerapkan dan melaksanakan kebijakan upah minimum yang ditetapkan oleh pemerintah di setiap perusahaan berdasarkan amanat Undang-Undang Republik Indonesia Nomor 13 Tahun 2003 Tentang Ketenagakerjaan Pasal 90 ayat (1) yang berbunyi:

"Pengusaha dilarang membayar upah lebih rendah dari upah minimum sebagaimana dimaksud dalam Pasal 89."

Berdasarkan peraturan tersebut, pengusaha atau perusahaan melalui APINDO Kabupaten Karawang bertanggung jawab dalam penerapan kebijakan upah minimum yang telah ditetapkan dan diberlakukan di Kabupaten Karawang. Segi Standar Operasional Prosedur (SOP) yang menjadi acuan dalam implementasi kebijakan upah minimum di Kabupaten Karawang adalah Keputusan Gubernur Jawa Barat Nomor 561/Kep.983Yanbangsos/2019 Tentang Upah Minimum Kabupaten/Kota di Daerah Provinsi Jawa Barat Tahun 2020. Namun, acuan yang dijadikan SOP dalam penerapan kebijakan upah minimum di Kabupaten Karawang terdapat ketidaksempurnaan hukum atau cacat hukum. Hal tersebut dikarenakan Gubernur Jawa Barat mengesahkan UMK
Karawang tanpa ada kesepakatan upah antara pengusaha dan pekerja/buruh.

Pengawasan dalam implementasi kebijakan upah minimum pada perusahaan di Kabupaten Karawang dilakukan oleh Dinas Tenaga Kerja dan Transmigrasi Kabupaten Karawang. Dalam hal ini, peneliti mengetahui bahwa pengawasan yang dilakukan oleh Dinas Tenaga Kerja dan Transmigrasi Kabupaten Karawang masih kurang tegas seperti hanya menegur dan memberikan surat peringatan kepada perusahaan yang melanggar peraturan. Hal tersebut dikarenakan Dinas Tenaga Kerja dan Transmigrasi Kabupaten Karawang tidak memiliki kewenangan lebih dari itu, sehingga jika terjadi pelanggaran yang dilakukan oleh pihak pengusaha atau perusahaan Dinas Tenaga Kerja dan Transmigrasi Kabupaten Karawang melaporkan dan berkoordinasi dengan Dinas Tenaga Kerja dan Transmigrasi Provinsi Jawa Barat untuk ditindak lebih lanjut. Pemberian sanksi jika terjadi pelanggaran dalam proses implementasi kebijakan upah minimum di Kabupaten Karawang telah diatur dalam Pasal 185 Undang-Undang Republik Indonesia Nomor 13 Tahun 2003 Tentang Ketenagakerjaan bahwa pengusaha atau perusahaan yang membayarkan upah kepada pekerja/buruh lebih kecil dibawah upah minimum yang telah ditentukan oleh pemerintah dapat dikenai sanksi pidana penjara paling singkat 1 (satu) tahun dan denda paling sedikit Rp 100.000.000,00 (seratus juta rupiah).

\section{Kondisi-Kondisi Ekonomi, Sosial, dan Politik}

Kondisi ekonomi, sosial, dan politik yang tidak kondusif pun dapat menjadi salah satu penyebab kegagalan dalam mengimplementasikan kebijakan. Peneliti mengetahui bahwa sumber daya ekonomi perusahaan padat karya cukup kesulitan mengikuti kebijakan upah minimum di Kabupaten Karawang karena kapasitas keuangan perusahaan tidak memadai jika harus membayarkan upah tidak boleh lebih rendah dari UMK Karawang yaitu sebesar Rp 4.594.324,00. Hal tersebut, dikarenakan perusahaan padat karya memiliki biaya produksi yang mahal, sebab masih banyak menggunakan sumber daya manusia dalam proses produksinya. Sehingga banyak 
pabrik yang bergerak di industri textile tutup/pindah dari Kabupaten Karawang karena tidak mampu membayarkan UMK Karawang yang terlalu tinggi.

Implementasi kebijakan upah minimum ini mampu memberikan pengaruh terhadap kondisi ekonomi dan sosial khususnya di Kabupaten Karawang. Pengaruh dari implementasi kebijakan upah minimum terhadap kondisi ekonomi yaitu dapat memperbaiki perekonomian pekerja/buruh sehingga daya beli dan laju pertumbuhan ekonomi masyarakat mengalami peningkatan. Hal tersebut juga mempengaruhi kehidupan sosial di masyarakat, seperti banyaknya penggangguran akibat dari pengurangan pekerja/buruh dan perusahaan yang tutup/pindah keluar daerah karena tidak mampu membayarkan upah sesuai dengan UMK Karawang. Menurut data dari BPJS Ketenagakerjaan Kantor Cabang Karawang, terhitung mulai bulan Januari-Juni 2020 sebanyak 13.685 pekerja/buruh yang telah mencairkan Jaminan Hari Tua (JHT).

Kebijakan upah minimum yang ada di Kabupaten Karawang adalah kebijakan Upah Minimum Kabupaten/Kota (UMK), yang direkomendasikan oleh Bupati kepada Gubernur (berdasarkan hasil kesepakatan pengusaha dan pekerja/buruh) untuk disahkan dan diimplementasikan oleh pengusaha atau perusahaan. Kebijakan upah minimum di Kabupaten Karawang mendapatkan dukungan dan respon baik dari masyarakat khususnya pekerja/buruh dan para elit-elit politik maupun pemerintah, karena ikut terlibat dalam proses musyawarah kesepakatan upah melalui Dewan Pengupahan Kabupaten Karawang.

6. Kecenderungan Pelaksana (Implementor)

Implementasi kebijakan yang berhasil harus diikut oleh pemahaman terhadap kebijakan tersebut secara menyeluruh. Kebijakan yang dilaksanakan merupakan hasil perencanaan dari para pelaksana kebijakan itu sendiri. Pengusaha atau perusahaan sebagai pelaksana utama kebijakan upah minimum khususnya di Kabupaten Karawang sudah cukup memahami kebijakan upah minimum tersebut baik secara isi, tujuan, sasaran dan teknis pelaksanaannya.
Proses implementasi kebijakan upah minimum Kabupaten Karawang diawali dengan ditetapkannya besaran upah oleh Gubernur yang tercantum pada Keputusan Gubernur Jawa Barat Nomor 561/Kep.983Yanbangsos/2019 Tentang Upah Minimum Kabupaten/Kota di Daerah Provinsi Jawa Barat Tahun 2020. Pengusaha atau perusahaan membayarkan upah minimum yang sudah ditetapkan kepada pekerja/buruh dimulai pada bulan Januari hingga Desember tahun 2020. Jika pengusaha atau perusahaan tidak mampu membayarkan upah sesuai dengan peraturan tersebut, dapat melakukan penangguhan upah atas kesepakatan bersama pekerja/buruh dan kemudian disahkan oleh Gubernur melalui Dinas Tenaga Kerja dan Transmigrasi Provinsi Jawa Barat.

Keberhasilan implementasi kebijakan dapat diraih jika mendapat dukungan dan persetujuan para pelaksana kebijakan. Namun, dalam hal ini Apindo DPK Karawang menolak kebijakan upah minimum yang ditetapkan Pemerintah Provinsi Jawa Barat karena terdapat ketidaksempurnaan hukum atau cacat hukum dalam proses penetapan upah minimumnya tidak ada kesepakatan antara pengusaha dengan pekerja/buruh.

\section{KESIMPULAN}

Berdasarkan hasil penelitian dan pengamatan serta pengumpulan informasi dan data-data mengenai implementasi kebijakan upah minimum pada perusahaan di Kabupaten Karawang maka dapat diambil kesimpulan sebagai berikut:

1. Ukuran dan tujuan dari implementasi kebijakan tentang upah minimum Kabupaten/Kota pada perusahaan di Kabupaten Karawang tercapainya tujuan dari implementasi kebijakan ini, yaitu kesejahteraan hidup pekerja/buruh meningkat khususnya kesejahteraan secara finansial. Hal tersebut ditandai dengan penurunan jumlah presentase penduduk miskin di Kabupaten Karawang dalam kurun waktu 3 (tiga) tahun terakhir.

2. Sumber-sumber daya untuk membantu dalam proses implementasi kebijakan tentang upah minimum Kabupaten/Kota pada perusahaan di Kabupaten 
Karawang terdiri dari sumber daya manusia yaitu pengusaha atau investor yang mendirikan perusahaan dan sumber daya finansial yang bersumber dari keuntungan penjualan hasil produksi. Terdapat kelemahan pada sumber daya finansial yaitu ketidaksedian dana anggaran perusahaan untuk membayarkan upah kepada pekerja/buruh karena krisis ekonomi yang disebabkan oleh pandemi Covid-19.

3. Komunikasi dan kegiatan pelaksana dalam implementasi kebijakan tentang upah minimum Kabupaten/Kota pada perusahaan di Kabupaten Karawang yaitu dengan sosialisasi dan koordinasi antara pengusaha dengan pemerintah melalui surat menyurat atau media sosial, kegiatan wajib lapor, dan musyawarah bipartit dengan pekerja/buruh. Terdapat kekurangan dalam proses kegiatan wajib lapor yang hanya dilakukan 1 (satu) tahun sekali.

4. Karakteristik pelaksana kebijakan dalam proses implementasi kebijakan tentang upah minimum Kabupaten/Kota pada perusahaan di Kabupaten Karawang memiliki kompetensi yang cukup memadai. Selain itu, pengawasan yang dilakukan oleh Dinas Tenaga Kerja dan Transmigrasi Kabupaten Karawang tidak cukup tegas karena tidak mempunyai kewenangan lebih untuk menindak lanjuti jika terjadi kasus pelanggaran.

5. Kondisi ekonomi, sosial, dan politik dalam proses implementasi kebijakan tentang upah minimum Kabupaten/Kota pada perusahaan di Kabupaten Karawang yaitu dapat memperbaiki perekonomian pekerja/buruh sehingga daya beli dan laju pertumbuhan ekonomi masyarakat mengalami peningkatan. Hal tersebut juga mempengaruhi kehidupan sosial di masyarakat, seperti banyaknya penggangguran akibat dari pengurangan pekerja/buruh. Kebijakan ini mendapatkan dukungan dan respon baik dari masyarakat khususnya pekerja/buruh dan para elit-elit politik maupun pemerintah, karena ikut terlibat dalam proses musyawarah kesepakatan upah melalui Dewan Pengupahan Kabupaten Karawang.

6. Kecenderungan/sikap pelaksana dalam proses implementasi kebijakan tentang upah minimum Kabupaten/Kota pada perusahaan di Kabupaten Karawang, pengusaha atau perusahaan sebagai pelaksana utama kebijakan upah minimum khususnya di Kabupaten Karawang menolak kebijakan upah minimum yang ditetapkan Pemerintah Provinsi Jawa Barat karena terdapat ketidaksempurnaan hukum atau cacat hukum dalam proses penetapan upah minimumnya tidak ada kesepakatan antara pengusaha dengan pekerja/buruh.

\section{E. DAFTAR PUSTAKA}

\section{Buku-buku:}

Kadji, Yulianto. 2015. Formulasi Dan Implementasi Kebijakan Publik Kepemimpinan Dan Perilaku Birokrasi Dalam Fakta Realitas. Gorontalo : UNG Press Gorontalo.

Winarno, Budi. 2013. Kebijakan Publik Teori, Proses, Dan Studi Kasus. Yogyakarta : CAPS (Center of Academic Publishing Service).

\section{Dokumen Resmi:}

Undang-Undang Republik Indonesia Nomor 13 Tahun 2003 Tentang Ketenagakerjaan.

Peraturan Menteri Ketenagakerjaan Republik Indonesia Nomor 15 Tahun 2018 Tentang Upah Minimum.

Peraturan Menteri Negara Pendayagunaan Aparatur Negara Nomor 4 Tahun 2007 Tentang Pedoman Umum Formulasi, Implementasi, Evaluasi Kinerja dan Revisi Kebijakan Publik Di Lingkungan Lembaga Pemerintah Pusat dan Daerah.

Keputusan Gubernur Jawa Barat Nomor 561/Kep.983-Yanbangsos/2019

Tentang Upah Minimum Kabupaten/Kota di Daerah Provinsi Jawa Barat Tahun 2020.

\section{Internet:}

Aprian, Dony. Terhitung 2019, Realisasi Investasi di Karawang Capai Rp 24,2 Triliun. Diakses 22 Oktober 2020. Diakses dari https://amp.kompas.com/regional/read/ 2020/02/11/17495601/terhitung-2019- 
realisasi-investasi-di-karawang-capairp-242-triliun

Badan Pusat Statistik Kabupaten Karawang. Presentase Penduduk Miskin (Persen), 2017-2019. Diakses 22 Oktober 2020. Diakses dari https://karawangkab.bps.go.id

Cermati. BPS: Rata-rata Gaji Pegawai di Indonesia hanya $R p$ 2,79 Juta. Diakses 31 Januari 2020. Diakses dari https://kumparan.com/cermati- content/bps-rata-rata-gaji-pegawai-diindonesia-hanya-rp-2-79-juta1r79pwueF5q

Radar Sukabumi. Pabrik di Karawang Masih Mati Suri, Ratusan Buruh Dipecat, Belasan ribu Dirumahkan. Diakses 06 September 2020. Diakses dari https://radarsukabumi.com/jawabarat/karawang/pabrik-di-karawangmasih-mati-suri-ratusan-buruh-dipecatbelasan-ribu-dirumahka/ 